\title{
Metodologiczne problemy historii powojennego dokumentu filmowego w Polsce
}

\author{
MAREK HENDRYKOWSKI
}

\section{Wprowadzenie}

Polski film dokumentalny okresu powojennego stanowi wciąż nie do końca rozpoznane terytorium badawcze, które nadal dostarcza historykom kina cennego i ciekawego materiału do eksploracji, a wraz z nim wielu intrygujących impulsów. Kwestią o podstawowym znaczeniu jest dzisiaj głęboka rewizja dotychczasowych poglądów na jego temat. Wiąże się ona nie tylko z nieustannym poszerzaniem (niezmiernie wąskiej do niedawna) bazy źródłowej, do której współczesny badacz ma już dostęp, lecz także z zasadniczymi różnicami w zakresie metodologii.

Różnice te występują przede wszystkim w określeniu sfery przedmiotu badań, ale zaznaczają się także w sposobie podejścia do niego. Wszystkie one dotyczą rekonstrukcji wcześniejszego obrazu: rewizji zasobu istniejących źródeł oraz daleko idącej zmiany, którą wywołały alternatywne sposoby odczytania złożoności fenomenu, jakim okazuje się rodzimy dokument lat 1944-1955. Rzec można, iż poszerzony, zrewidowany i skorygowany przedmiot studiów uruchomił w rezultacie nowy dyskurs i vice versa.

Zanim powstanie historyczna synteza filmowego dokumentu i tzw. kina faktów pierwszego dziesięciolecia po wojnie, warto najpierw uświadomić sobie, iż gruntowna korekta nowego spojrzenia, którą będzie ona zawierać, wynika z odmienności opisu, analizy i interpretacji badanego przedmiotu. „Nowość” zaproponowanego w tym miejscu ujęcia nie jest absolutna. Ma ona swoje początki we wcześniejszych badaniach i rewizjach prowadzonych między innymi przez: Alinę Madej[1], Marka Halberdę[2], Wacława Świeżyńskiego[3], Edwarda Zajička[4], Jolantę Lemann[5], Marka Cieślińskiego[6], Marka Hendrykowskiego[7], Ewę Gębicką[8] i Piotra Zwierzchowskiego[9].
Nadszedł jednak czas, aby postawić kolejne pytania, wyznaczyć odmienne kierunki refleksji badawczej i wskazać alternatywne drogi interpretacji, a także dokonać bardziej adekwatnej i gruntowniejszej niż dotąd rewaluacji osiągnięć rodzimego dokumentu w tamtym okresie.

Cel nadrzędny stanowi dla nas ponowne rozpatrzenie i odczytanie tego fragmentu historii rodzimej kinematografii. Aby tego dokonać, trzeba będzie nie tylko przyjąć szereg trafnych rozpoznań dokonanych przez grono wymienionych wyżej poprzedników, ale też odrzucić pobieżne obserwacje, interpretacyjne uproszczenia i przedustawne sądy dotyczące wielu spraw uznanych wcześniej za definitywnie zbadane, oczywiste i bezdyskusyjne.

[1] A. Madej, Kino-władza-publiczność. Kinematografia polska w latach 1944-1949, Bielsko-Biała 2002.

[2] M. Halberda, Zjazd Filmowy w Wiśle, „Arka” 1990, nr 30.

[3] W. Świeżyński, Film dokumentalny (19441949), w: Historia filmu polskiego. Tom III: 1939-1956, red. J. Toeplitz, Warszawa 1974. [4] E. Zajiček, Poza ekranem. Kinematografia polska 1918-1991, Warszawa 1992.

[5] J. Lemann-Zajiček, Kino i polityka. Polski film dokumentalny 1945-1949, Łódź 2003.

[6] M. Cieśliński, Piękniej niż w życiu. Polska Kronika Filmowa 1944-1994, Warszawa 2006. [7] M. Hendrykowski, Paradoksy poetyki socrealizmu w filmie polskim, „Blok” 2002, nr 1.

[8] E. Gębicka, Kino w Polsce w latach 1944-1965. Polityka kulturalna. Ekonomia. Repertuar, dysertacja doktorska, Uniwersytet Wrocławski 1992. [9] P. Zwierzchowski, Pęknięty monolit. Konteksty polskiego kina socrealistycznego, Bydgoszcz 2005 (tutaj zwłaszcza analiza Szerokiej drogi Konstantego Gordona, 1949). 
Za horyzontem znikającej historyczności

Niezastąpiona rola historyków kina oraz historiografii filmowej dotyczącej okresu powojennego polega na ponownym odkrywaniu coraz mniej czytelnej i coraz bardziej zanikającej- historyczności zespołu wydarzeń i zjawisk, które ten okres niegdyś współtworzyły. Spróbujmy na początek sformułować kilka generalnych uwag i wskazówek, które ułatwią Czytelnikowi poruszanie się po tym, niekoniecznie doskonale mu znanym i czytelnym, obszarze.

Po pierwsze, wbrew dość powszechnie utrzymującemu się przekonaniu rodzima produkcja dokumentalna tamtego okresu nie jest zjawiskiem marginalnym, lecz pełnoprawnym - to znaczy równorzędnym wobec niesłusznie faworyzowanej i ponad miarę dowartościowanej jako pełnowymiarowa twórczość filmowa fabuły - elementem procesu historycznofilmowego. Procesu przemian produkcyjnych, realizacyjnych, estetycznych, a przede wszystkim ideologicznych, który w zasadniczy sposób zmienił wówczas od podstaw polską kinematografię.

Po drugie, dokument filmowy okresu 19441955 jako przedmiot badań i naukowych dociekań nie jest żadnym monokulturowym monolitem; wprost przeciwnie, zawiera w sobie wiele różnych dążeń i podstawowych sprzeczności. Jego skomplikowany rozwój nie przebiegał linearnie, na drodze ewolucyjnego następstwa, lecz podlegał intensywnym zmianom i przekształceniom wynikającym $\mathrm{z}$ nieustannych konfliktów, jakie dawały o sobie znać w tej dziedzinie. Konfliktów, do których dochodziło zarówno wewnątrz środowiska reprezentującego rozmaite postawy i dążenia, jak i w relacjach zachodzących pomiędzy filmowcami a władzą.

Po trzecie, kategorią podstawową dla dalszych studiów i naukowych rozpoznań jest świadomość filmowa. To właśnie w systemie świadomości filmowej widać najlepiej, czym był ówczesny dokument, jakie funkcje pełnił, jakie istniały wobec niego oczekiwania $\mathrm{i}$ jak ówczesna świadomość dokumentu - odzwierciedlona w praktyce społecznego komunikowania $-\mathrm{z}$ biegiem lat ewoluowała. Jej wyrazem są zarówno poszczególne zapisy na taśmie (traktowane przez nas jako poddające się opisowi, analizie i interpretacji teksty kultury), jak i szeroko rozumiany kontekst danego miejsca i czasu, ze szczególnym podkreśleniem: zespołu uwarunkowań, w jakich materiały te powstawały, oraz stylów odbioru (resp. recepcji dokumentu), także będących integralnym elementem systemu świadomości filmowej.

Po czwarte, środowisko filmowców dokumentalistów nie było grupą jednorodną, wręcz przeciwnie, tworzyło zbiorowość bardzo zróżnicowaną. Ludzie wykonujący ten zawód trafiali do niego z odmiennym doświadczeniem życiowym, praktyką zawodową, a przede wszystkim z bardzo różnymi (Bossak, Wohl, Perski, bracia Forbertowie, bracia Sprudinowie, Brzozowski, Brzozowska, Rodowicz, Urbanowicz, Jaryczewski, Świdwiński, Kaźmierczak, Wawrzyniak, Lemańska, Bohdziewicz, Makarczyński, Munk, Karabasz i inni) biografiami. Poszczególne przemilczane epizody tych życiorysów często nie znajdowały żadnego odzwierciedlenia w ankiecie personalnej szeregowego pracownika podejmującego etatową pracę w instytucjach znacjonalizowanej po wojnie kinematografii.

Po piąte, dokument filmowy był niewątpliwie narzędziem w ręku aparatu ideologicznego służącym propagandzie nowego ustroju, ale oprócz tego był również dziedziną i formą swoiście pojętej twórczości. Permanentny - momentami bardzo ostry - konflikt racji między filmowcami a władzą dotyczy funkcji dokumentu jako kronikalnego świadectwa swego czasu. Nieustannie daje w nim o sobie znać polaryzacja postaw i dylemat, czy medium kina i ten rodzaj przekazu społecznego mają wyrażać wyłącznie oficjalne stanowisko i punkt widzenia władzy, czy też historyczność dokumentu ma być eksponowana poprzez zapisany na taśmie obraz losów i działań człowieka bądź zbiorowości.

Po szóste, nawet w najbardziej niesprzyjających warunkach tamtych lat mimo wszystko daje o sobie znać autorski charakter i wymiar pracy polskiego filmowca dokumentalisty. Aspekt ten był wartością niepożądaną dla wła- 
dzy ze względu na przymieszkę subiektywizmu w pracy, która „z natury swej” miała obiektywizować w oczach widza wszystko, co pojawia się w przekazie. Pojawiał się jednak nawet w przekazach skądinąd całkowicie podporządkowanych ideologii realnego socjalizmu.

Po siódme, mitem jest przeświadczenie, iż państwo zapewniało filmowcom odpowiednie warunki do profesjonalnego uprawiania zawodu. Wysłużony sprzęt, na którym pracowali, był sprzętem pochodzącym $z$ wojennego demobilu[10]. Po wojnie przez długi czas kinematografii brakowało środków na zakup nowoczesnych kamer i niezbędnej aparatury. W tych warunkach i przy takim wyposażeniu liczyła się przede wszystkim inwencja oraz warsztatowe umiejętności. Szereg powojennych dokonań polskiego dokumentu zasługuje na uznanie czy wręcz podziw, między innymi ze względu na zaprezentowaną w nich zdolność realizatorów do pokonywania i przekraczania istniejących ograniczeń.

Po ósme, ograniczeniem nieporównanie bardziej krępującym twórczą inicjatywę była stała presja ideologiczna. Wprawdzie najwyższe czynniki partyjne zajmowały się wtedy na bieżąco tylko filmem fabularnym, a dokumentem jedynie okazjonalnie. Istniała jednak na co dzień także przemożna presja aparatu niższego szczebla wywierana na filmowców przez czynniki polityczne. W warunkach państwowego monopolu liczyły się: doraźne zamówienia, aktualne tematy, wskaźniki ekonomiczne, limity taśmy, normy produkcyjne, nakazy, zakazy i niezliczone dyrektywy. Wszystko inne, $\mathrm{z}$ twórczością na czele, musiało być podporządkowane tym - coraz bardziej krępującym wszelką inicjatywę - wymogom.

Po dziewiąte, niezbywalny kontekst tej odmiany twórczości filmowej stanowiła komunistyczna cenzura: niczym terytorium przygraniczne czujnie strzeżona zarówno przez tropiącą wszelkie odchylenia ideowe administrację kinematografii, jak i przez instytucjonalną cenzurę wraz z jej agendami w Filmie Polskim, Centralnym Urzędzie Kinematografii i Wytwórni Filmów Dokumentalnych. Nie- cenzuralne w dokumencie mogło okazać się dosłownie wszystko. Nieustanna obawa przed posądzeniem o nieprawomyślność filmowego przekazu, demonstracyjna aktywność cenzury oraz podskórna obecność nieodłącznej od niej autocenzury odcisnęły się mniej lub bardziej praktycznie w każdym filmie dokumentalnym tamtego okresu. To właśnie $\mathrm{z}$ tego względu specyficznej wymowy nabiera zarówno względna wolność pierwszych lat dokumentu w powojennej Polsce, jak i symptomy odwilży politycznej obserwowane w latach 1954-1955.

I po dziesiąte, ponowne odczytanie historii kina tego okresu zmierza do wydobycia kwestii różnic aksjologicznych dzielących poszczególne nakręcone wówczas filmy. Zniuansowanie ich wartości pozwoli badaczom historii powojennego dokumentu odkryć na nowo rzeczy cenne i oddzielić je od masy rutynowo kręconych tuzinkowych produkcji oraz przekazów propagandowych, których realizator nie operuje, lecz manipuluje wykorzystanym materiałem.

\section{Ethos dokumentalisty}

Wbrew potocznemu mniemaniu w filmach niefikcjonalnych nakręconych w tamtym okresie daje o sobie znać problematyka etyczna dokumentu filmowego związana $\mathrm{z}$ określoną postawą filmowca. Dochodzi w niej do głosu zasadnicza różnica pomiędzy posługiwaniem się określonymi kliszami, chwytami i środkami wyrazu a perfidną (mającą na celu sfalsyfikowanie faktycznego obrazu świata) manipulacją nimi. Samo kręcenie dokumentów w tamtym okresie, a także ich montowanie, symplifikowa-

[10] Intensywne poszukiwania prowadzone po zakończeniu wojny przez ekipę polskich filmowców, z Zygmuntem Szyndlerem na czele, na Ziemiach Odzyskanych i w okupowanych Niemczech doprowadziły do przejęcia sporej ilości profesjonalnego sprzętu filmowego. Sprzęt ten, podobnie jak zapasy taśmy negatywowej, służył naszej kinematografii przez wiele następnych lat. Zaczęło się jednak już podczas wojny, kiedy w 1943 roku Rosjanie przekazali na użytek Czołówki Filmowej Wojska Polskiego archaiczny model kamery statywowej Debrie Parvo. 
ło obraz człowieka i świata, ale nie było czymś szczególnie nagannym. Obecności klisz i matryc w przekazie tego rodzaju nie sposób było się całkiem ustrzec.

Prawdziwy problem $z$ dokumentem polegał na czym innym. Naganna w nim była wszelka manipulacja materiałem filmowym zmierzająca do wykreowania iluzyjnej rzeczywistości zastępczej. Refleksja poświęcona tej - podstawowej, a może nawet kluczowej dla charakterystyki kinematografii polskiej lat czterdziestych i pięćdziesiątych - problematyce należy jak najbardziej do zadań wartych wnikliwego podjęcia i leżących w gestii historyka filmu zainteresowanego tym okresem.

Służy temu między innymi - wprowadzone tutaj w odniesieniu do produkcji z lat 19491955 - rozróżnienie dwu kategorii filmów. Kategoria dokumentów okresu socrealistycznego (przypisana wspólnemu historycznemu kontekstowi istniejących okoliczności funkcjonowania wszelkich form ówczesnego filmu dokumentalnego) zostaje przez nas przeciwstawiona innej, skądinąd będącej integralną częścią tego zbioru, wyodrębnionej kategorii dokumentów stalinowskich. Jedne i drugie należą do przekazów dokumentalnych wyprodukowanych w tym samym miejscu i czasie. O wiele mniejszy zbiór posiadających swoiste cechy przekazu skrajnie zideologizowanego dokumentów stalinowskich jest podzbiorem zbioru pierwszego.

Czerpiący pełnymi garściami $\mathrm{z}$ arsenału środków i metod kina totalitarnego, a zwłaszcza $\mathrm{z}$ zaadaptowanych dla potrzeb rodzimej produkcji filmowej wzorców przeniesionych z kinematografii radzieckiej, dokument stalinowski, skrótowo rzecz ujmując, znamionowały: czynnik ideowo usprawiedliwionej manipulacji przekazem, oparte na demonstracyjnie podkreślanym alibi „nowego porządku dziejowego postępu" falsyfikowanie obrazu rzeczywistości

[11] Zob. na ten temat analogiczne spostrzeżenia i rozróżnienia Michała Głowińskiego zawarte w artykule Literatura $w$ Polsce Ludowej, literatura Polski Ludowej, w: idem, Rozmaitości interpretacyjne. Trzydzieści szkiców, Warszawa 2014, s. $141-150$. oraz agresywne przesłanie propagandowe wynikające $z$ ofensywy ideologicznej kina tamtej doby.

Przekaz perswazyjny wykorzystywany w takiej funkcji stawał się przekazem „w złej wierze”, świadomie operującym ewidentną - niekiedy groteskowo przerysowaną, niekiedy nad wyraz perfidną - manipulacją. Znaczna część innych filmów dokumentalnych omawianego okresu (reportażowe, oświatowe, krajoznawcze, popularnonaukowe, przyrodnicze, sportowe itp.) nie wykazuje jednak takich cech albo zawiera ich niewiele. Mamy zatem w polu badawczym dziejów polskiego dokumentu tej doby nie jeden, lecz dwa różne zbiory filmów będące wyrazem dalece odmiennych postaw i tendencji ich twórców.

Dla niewprawnego oka obie kategorie przekazu niczym szczególnym się nie różnią. $\mathrm{W}$ istocie jednak dwa wyróżnione tu zbiory dzieli niemało[11]. Pierwszy z tych zbiorów bez porównania bardziej rozległy, obejmujący swym zakresem filmy dokumentalne nakręcone w latach 1944-1955 - definiuje historyczna przynależność do grupy przekazów wyprodukowanych w warunkach znacjonalizowanej kinematografii polskiej tamtego okresu. Filmy te reprezentują bardzo różne gatunki, odmiany gatunkowe, a także zróżnicowane strategie i postawy twórcze. Można powiedzieć, iż łączący je wspólny mianownik stanowi jedynie tożsamy dla każdego z nich kontekst czasu i miejsca powstania - okoliczności z istoty swej uwikłanych w politykę i propagandę nowego ustroju.

Inaczej przedstawia się kwestia $\mathrm{z}$ drugą kategorią przekazów. Bez porównania węższy od filmów dokumentalnych okresu socrealistycznego, zbiór filmów określanych przez nas umownym mianem „dokumentów stalinowskich” posiada wyraziście zdefiniowany wspólny mianownik w postaci presji matrycy ideologicznej. Ich wirtualny autor (cudzysłów niekonieczny) okazuje się bytem jednorodnym i skrajnie zunifikowanym. Najczęściej toporne, ale bywa niekiedy, że zręczne w swej skuteczności, posługiwanie się przez niego ideologiczną matrycą sprawia, iż komunikat filmowy uchodzący za przekaz 
niefikcjonalny w perfidny sposób fikcjonalizuje obraz rzeczywistości, kreując zamiast niej zastępczą fantomatyczną pseudorealność.

Jej ekranowe urzeczywistnienie w postaci strumienia - zazwyczaj bezkrytycznie postrzeganych z całą ufnością jako najzupełniej realne - ruchomych obrazów staje się instrumentem przemocy symbolicznej, powołującej do istnienia przedmiot i wyraz nowej wiary. $\mathrm{W}$ procesie komunikowania daje to kolosalną przewagę funkcjonalną nadawcy nad odbiorcą. Realizator dokumentu stalinowskiego przyjmuje na siebie funkcję „inżyniera dusz”, pełniąc w filmie rolę agresywnego agitatora. Występuje on w konstrukcji przekazu jako ukryty manipulator, którego celem jest narzucenie za pomocą wszelkich dostępnych środków filmowego wyrazu określonej wizji świata zniewolonym umysłom widzów.

Należy jednak wyraźnie zaznaczyć, iż krytyczne odczytanie przez badacza tego typu procederów i nagannych zabiegów występujących w dokumencie stalinowskim nie daje żadnych podstaw do przemilczania bądź eliminowania problematyki z tym związanej. Zarówno jedna kategoria filmów (dokument okresu socrealizmu w różnych jego postaciach), jak i druga (mowa o skrajnie zideologizowanym i zmanipulowanym dokumencie stalinowskim) stanowi z punktu widzenia historyka filmu frapujący materiał badawczy, pod każdym względem równoprawny i zasługujący na uwagę. Fakt, że poszczególne przekazy w obu wyróżnionych wyżej odmianach były traktowane przez zleceniodawców jako narzędzie propagandy, raczej zwiększa, niż ogranicza zainteresowanie nimi jako swoiście pojętymi „tekstami kultury”.

Świadomość filmowa jako wyraz praktyki

Do spostrzeżeń powyższych warto dołączyć także inne. W każdej z tych refleksji jednakowo wyraziście dochodzi do głosu systemowe traktowanie filmowego dokumentu jako: 1) medium kinematograficznego; 2) specyficznej dziedziny twórczości; oraz 3) zbioru konwencji, stylów odbiorczych i środków wyrazu regulujących proces komunikowania.
Szczególną formą i wyrazem świadomości filmowej okresu powojennego jest ówczesna praktyka filmowego dokumentu. Należy ją rozumieć dostatecznie szeroko i zarazem konkretnie jako uzus: programowy, koncepcyjny, realizacyjny, administracyjno-decyzyjny, produkcyjny i dystrybucyjny, wraz z oceną wyników i promocją w kraju i za granicą. W polu jej oddziaływania sytuują się zarówno mechanizmy funkcjonowania instytucji kinematograficznych (Przedsiębiorstwo Państwowe Film Polski, Centralny Urząd Kinematografii, Wytwórnia Filmów Dokumentalnych, Polska Kronika Filmowa, Wytwórnia Filmów Oświatowych i inne podmioty), jak i indywidualne poczynania, inicjatywy oraz wybory poszczególnych twórców i realizatorów tej produkcji.

Kapitalne znaczenie dla wszelkich studiów nad tym okresem posiadają również świadectwa odbioru. Społeczny odbiór dokumentu filmowego w Polsce powojennej okazuje się wypadkową wielu różnych oczekiwań i wychodzacych im naprzeciw - albo całkiem zaprzeczających tym oczekiwaniom - realizacji. Czym innym jest odbiór danego przekazu jako zadanie ideologiczne dla władzy, czym innym - jego przyjęcie przez miliony ludzi spragnionych polskiego filmu na ekranie, a jeszcze czym innym - ten sam przekaz poddany krytyce przez znakomitą mniejszość sceptycznych obserwatorów (Maria Dąbrowska, Antoni Bohdziewicz, Krystyna Żywulska, Czesław Miłosz, Stefan Kisielewski, Leopold Tyrmand i inni), których w tamtym czasie nie brakowało.

Warto w tym miejscu uświadomić sobie charakterystyczną cechę typowej dla tamtego okresu recepcji filmów w kategoriach zwierciadła rzeczywistości. Taki sposób ich traktowania wytworzył styl odbioru, w którym fikcja i nie-fikcja stanowiły daleko posuniętą jedność. Wszystko, co ukazywało się na ekranie, niebezpiecznie zbliżało do siebie rzeczywistość i nierzeczywistość, czyniąc je na równi „prawdziwymi” ze względu na fotograficzny realizm (resp. wiarygodność) sfilmowanych zdarzeń, sytuacji i wyglądów rzeczy. 
Tak więc Zakazane piosenki i Ostatni etap $\mathrm{w}$ zetknięciu $\mathrm{z}$ ówczesną widownią traciły status fikcji ekranowej, stając się w jej oczach sui generis dokumentem zastępczym o życiu w okupowanej Warszawie, o straszliwym świecie obozów koncentracyjnych itp., podczas gdy rozmaite nieprawdopodobieństwa i ewidentne szalbierstwa przedstawień udających dokument mogły liczyć na bezkrytyczne przyjęcie i aprobatę odbiorcy pod warunkiem, że ten uważał oglądany film za sfilmowaną rzeczywistość.

Mamy tutaj do czynienia ze szczególną formą zniewolonej świadomości filmowej, i nie tylko filmowej, uwikłanej w politykę i ideologię. Urzędowa świadomość doktryny realizmu socjalistycznego sprowadzała się w gruncie rzeczy do kilku obiegowych sloganów i wygłaszania czczych ogólników w rodzaju: sztuki postępowej, walczącej o sprawiedliwość społeczną i pokój na świecie, głoszącej wyższość nowego ustroju, ukazującej ekranowych bohaterów w funkcji ideowego wzorca dla mas itp.

Labilność i względność w tak ogólnikowy sposób formułowanych na gruncie polskim kryteriów ideologicznych i estetycznych miały swoją zarówno negatywną, jak i pozytywną stronę. Paradoksalnie otwierały bowiem przed filmowcami (zarówno fabularzystami, jak i dokumentalistami) pewien margines niedookreślenia i zarazem pole - skromnego wprawdzie, ale jednak - twórczego manewru. W dokumencie było zresztą o to odrobinę łatwiej niż w szczególnie czujnie nadzorowanej fabule. Nie oznacza to wcale przywileju wolności dla realizatorów dokumentu. Cenzura (i autocenzura) w produkcji dokumentalnej wyglądała jednak inaczej niż przy filmie fabularnym.

[12] W Polskiej Kronice Filmowej taki zmontowany na gotowo i dopuszczony do rozpowszechniania, złożony $\mathrm{z}$ różnych materiałów wielotematyczny przekaz nosił nazwę wydania, a w innych gatunkach dokumentu był on: filmem polityczno-propagandowym, reportażem wojennym, produkcyjniakiem, filmem montażowym, relacją, sprawozdaniem, filmowym portretem, reportażem $z$ podróży, filmem oświatowym, instruktażowym, satyrą, poematem dokumentalnym etc.
Terminologiczną użyteczność zachowuje w studiach nad kinematografią (nie tylko) tego okresu rozróżnienie materiału filmowego i filmu dokumentalnego jako samoistnego utworu. Jedno i drugie pozostawało „dokumentem", ale między zdokumentowanym na taśmie nieocenzurowanym materiałem zdjęciowym a wprowadzanym $\mathrm{w}$ obieg kinowy i na tysiące ekranów ocenzurowanym przekazem dokumentalnym[12] istniała zasadnicza różnica nie tylko formalna. Szefowie Polskiej Kroniki Filmowej Jerzy Bossak (w latach 1944-1949), a po nim Helena Lemańska (do 1967 roku) prowadzili konsekwentnie politykę rejestrowania i przechowywania w archiwum Wytwórni Filmów Dokumentalnych rzeczy niekoniecznie cenzuralnych, wychodząc z założenia, że mogą się one kiedyś jeszcze przydać.

Fakt, że dokument - podobnie jak cała ówczesna kinematografia - był uważany przez władze za narzędzie propagandy i legitymizacji nowego ustroju, nie likwiduje w badaniach nad dziejami kina lat 1944-1955 problematyki podmiotowości i autorstwa. Władza stworzyła i utrzymywała kinematografię na własny użytek. Filmowcy wiedzieli, dla kogo pracują. Obie strony uprawiały grę. $\mathrm{Z}$ biegiem czasu wytworzył się obustronny kompromis, rzadko tylko zakłócany „wypadkami przy pracy” i in cydentami w rodzaju szokująco odmiennego od obowiązującego paradygmatu Mojego miasta Wojciecha Jerzego Hasa (1950).

Warto pod tym kątem odczytać właściwy sens atrybucji wszelkich materiałów filmowych. To, iż były one bezwarunkowo ewidencjonowane i sygnowane nazwiskiem realizatora, nie oznacza, że w warunkach zmonopolizowanej państwowej kinematografii, a tym bardziej pod dyktatem doktryny socrealizmu, mieliśmy do czynienia $\mathrm{z}$ dokumentem autorskim. Powiedzmy wprost: obligatoryjne sygnowanie wszelkich nakręconych materiałów imieniem i nazwiskiem realizatora było dla administracji bynajmniej nie sygnałem przyzwolenia na autorski charakter przekazu, lecz kontrolnym znakiem rozpoznawczym podmiotu sprawczego (czytaj: sprawcy) na wypadek personalnej 
odpowiedzialności za nieprawomyślną wymowę materiału i przekazu.

Materiał filmowy - zamówiony, wskazany i wyprodukowany przez zleceniodawcę, nakręcony przez operatorów, opisany w katalogu tematów i przechowywany w filmowym archiwum - zawierał w sobie doraźne, cząstkowe znaczenie. Przed montażem jego zakotwiczenie w realnej rzeczywistości określonego tu i teraz pozostawało kwestią nader względną i mało istotną. Desemantyzacja pierwotnej zawartości znaczeniowej danego obrazu na stole montażowym była praktyką codzienną, wiele mówiącą o ówczesnej świadomości dokumentu i sposobie jego traktowania.

Materiały takie wykorzystywano wielokrotnie na zasadzie montażowego recyklingu. Nieważne, kto je nakręcił. Były one czymś z istoty swej niesamodzielnym, co posłuży dopiero do wykreowania przekazu stanowiącego konstrukcję wyższego rzędu, obdarzonego autonomią własnej struktury, niosącego określoną informację i przesłanie ideologiczne. Liczył się w nich wyraziście ujęty temat, a nie autor zdjęć.
Dokumentalista tamtej doby nie był nikim więcej niż wykonawcą zleceń, sprawnym wytwórcą filmowych tematów. Niczego ponad to od niego nie oczekiwano.

Z drugiej strony jest jednak bezspornym faktem, że Ballada f-moll (1945) Andrzeja Panufnika, Łopuszna - ziemia nieznana (1945), Suita warszawska (1946) i Szlembark (1948-56) Tadeusza Makarczyńskiego, Wieliczka (1946) Jarosława Brzozowskiego, Powódź (1947) Jerzego Bossaka, Kopalnia (1947) Natalii Brzozowskiej, Ulica Brzozowa (1947) i Moje miasto (1950) Wojciecha J. Hasa, Kolejarskie słowo (1953) i Niedzielny poranek (1955) Andrzeja Munka oraz dziesiątki innych filmów dokumentalnych wówczas nakręconych miały swoich autorów. Dzięki temu, nie tracąc z pola widzenia rozmaitych okoliczności złożonego kontekstu, w jakim te produkcje powstawały, możemy dzisiaj z uwagą studiować ukryty przed nieprofesjonalistą sens tych produkcji i z dumą mówić o znakomitych tradycjach polskiego dokumentu, który w tamtych trudnych czasach zdołał mimo wszystko ocalić własną twarz.

\section{Wycieczka w nieznane}

\section{Rozmowa z Lechosławem Trzęsowskim, operatorem filmowym, autorem zdjęć do szkolnych etiud Krzysztofa Kieślowskiego Urząd (1966) i Koncert życzeń (1967)}

\begin{abstract}
Mikołaj Jazdon: Czy rozpoczynając studia w Szkole Filmowej w Łodzi, miał Pan za sobą jakieś doświadczenia $\mathrm{z}$ filmem lub fotografią?
\end{abstract}

Lechosław Trzęsowski: Tak, miałem raczej amatorskie doświadczenia i z fotografią, i z filmem. Fotografii nauczył mnie mój ojciec Stanisław Trzęsowski, i to używając starego, poniemieckiego aparatu mieszkowego o formacie 9x12 cm. Fotografowałem razem $\mathrm{z}$ ojcem na szklanych płytach ortochromatycznych, nieczułych na kolor czerwony. Miało to tę zaletę, że płyty szklane mogliśmy razem wywoływać w kuchni na talerzach przy użyciu czerwonego światła, aby było coś widać. Następnie robiło się odbitki kontaktowe na papierze. Szklana płyta z negatywowym obrazem była kładziona na papier światłoczuły (cały czas przy czerwonym oświetleniu kuchni) i na kilka sekund było włączane światło normalnej żarówki. Jakość tych kontaktowych odbitek nie była gorsza 